\title{
The wild plants of Scotia I/lustrata (1684)
}

\author{
Lee Raye \\ Cardiff University, Wales, UK
}

Corresponding author: Lee Raye: lee.raye@gmx.co.uk

This pdf constitutes the Version of Record published on $31^{\text {st }}$ August 2020

\begin{abstract}
Scotia Illustrata was published in 1684 and contains a section (II:1) describing 662 'naturally occurring plants of Scotland'. This paper sets out to identify and discuss the species in the text. It was possible to identify 652 species from the text and 396 could be securely identified. Most of these are species which are widespread today, but there are some important exceptions. Three arable weeds are mentioned which now seem to be extinct in Scotland: Lolium temulentum, Scandix pecten-veneris and Euphorbia exigua. There are also references to one possibly-extinct river species (Sium latifolium), and one coastal species (Centaurea calcitrapa). Two species, now rare in Scotland, are described in the text as species widespread on roads:

Cynoglossum officinale and Hyoscyamus niger.
\end{abstract}

Keywords: Robert Sibbald; $17^{\text {th }}$ century Scotland; botanical history; species history; regional natural history

\section{Introduction}

Scotia Illustrata (Sibbald, 1684) is an early modern description of Scotland written mainly in Latin with notes in Scots and English. The text fits into the genre of the Baconian regional natural history: a collaborative text which aimed to catalogue an area's natural resources with the aim of maximising productivity and discovering all possible resources for exploitation and extraction. This genre was first popularised in response to a questionnaire circulated by Robert Boyle of the Royal Society of London called the General Heads for the Natural History of A Country, Great or Small, (M. Boyle, 1665; R. Boyle, 1666). In terms of scope, Scotia Illustrata may be the one of the most ambitious regional natural histories, since it describes the whole of Scotland rather than a single county like most of the others. Texts in the genre were mainly written by writers connected with the correspondence network of the Royal Society, in order to catalogue the natural resources of counties in Britain and Ireland. (e.g. Aubrey, 1691; Childrey, 1662; Emery, 1977; Plot, 1677, 1686; Smith, $1746,1750)$. Each natural history was informed by a questionnaire sent to local informants (Cooper, 2007, pp. 116-140; Fox, 2010). Withers (2001, pp. 256-262) has counted 77 principal respondents to the questionnaire written by Robert Sibbald to inform Scotia Illustrata, and many of these responses have been printed separately in Macfarlane's Geographical Collections Relating to Scotland series (A. Mitchell, 1908). Mapping these contributions on a topographic map (see Fig. 1) reveals a bias towards higher-populated lowland Scotland. The comparative lack of 
information about the Highlands and Islands in this period made Martin Martin and other Gaelic-speaking informants especially valuable (Withers, 2001, pp. 87-91).

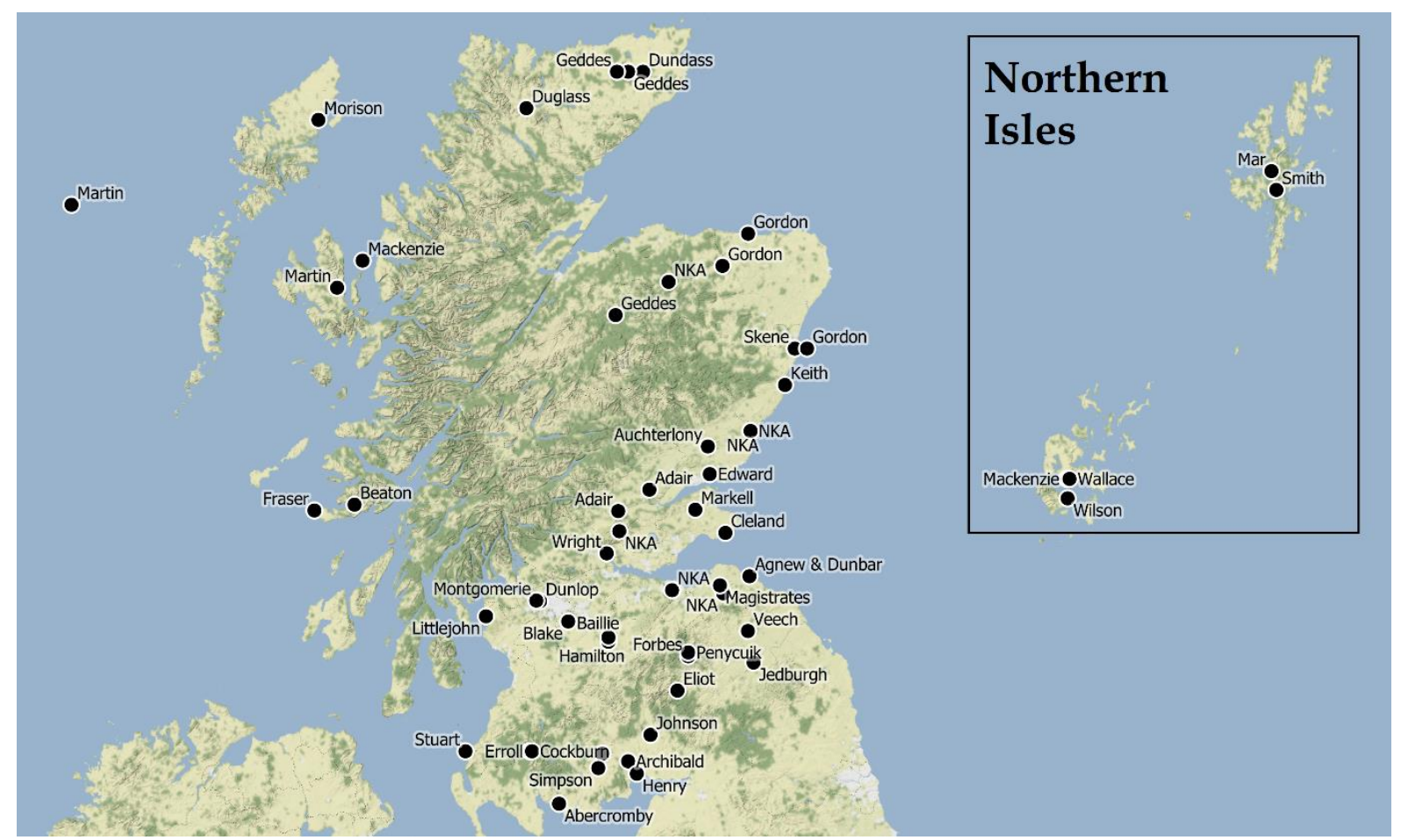

Figure 1. Map of the locations described in contributions to Scotia IIlustrata II:1 (using the list by Withers, 2001, pp. 256-262). Some of the labels in high-density areas have been hidden. Orkney and Shetland are shown on the inset. Map tiles by Stamen Design, under CC BY 3.0, using data by OpenStreetMap, under ODbL.

Original version of map without labels appeared in my translation of Sibbald (2020), used with permission.

It is worth noting that although the regional natural histories were all interested in increasing productivity, Scotia Il/ustrata was motivated more by compassion than by financial profit. The author (in the sense that he compiled, contextualised and edited the data) of Scotia Illustrata was Robert Sibbald (16411722). Sibbald was a physician who shared the common conviction of the time period that each area was furnished with the natural medicines needed to treat the diseases found in that area (Sibbald, 1833, p. 21). In that sense, Scotia Illustrata offered a possibility to create knowledge about new medicines. Sibbald was also a humanitarian, and believed that greater knowledge of the medical resources of an area could help provide free treatments to the poor in that area (Sibbald, 1684, p. i (II:3)). Compiling the data for Scotia Illustrata also undoubtedly helped Sibbald a decade later, when, in the famine of the seven ill years he provided a guide to wild foraging for the use by the starving populace (Sibbald, 1699).

The focus of this paper is on Scotia Illustrata part II, book 1 (hereafter II:1), which can essentially be thought of as a floral checklist or flora, describing the wild and naturalised plants of seventeenth century Scotland. A translation of this section is now available (Sibbald, 2020). This section consists of an A-Z list of wild plant genera found in Scotland with some supplementary information about each. The text 
includes 659 species; mostly plants (including herbaceous plants, shrubs and trees), but also some seaweeds and fungi. Since the text was published in 1684, it predates several important influences in the history of the flora which have led to declines in species and habitat richness (Dodgshon, 2005; Ingrouille, 1995, pp. 265273; Lusby, 1998; Preston et al., 2003): It was written during the Late Maunder Minimum of the so-called 'Little Ice Age' and before the intensification of agriculture and pesticide use, the loss of meadows and much of the standing water drainage. It was also written before major land management changes including Highland clearances, the popularisation of grouse moors, and severe increase of pressure from mining, roads and development. The aim of this paper is therefore to identify the species referred to in the text, and then discuss broadly what the presence of these species suggests about the changes that occurred in Scotland's habitats between the seventeenth and twenty-first centuries.

\section{Methods}

In order to comment on the flora of Scotia II/lustrata II:1, it is first necessary to identify the 659 species mentioned in the text. Some of the plants in the text can be identified based on a modern knowledge of wild plants. The text offers four potential botanical clues:

1. A vernacular name is provided which matches the modern vernacular name of a particular species.

2. One or more of the polynomial names used contains or matches the accepted binomial name for a particular species.

3. A description is provided which matches a particular species.

4. A plate is provided (rare) which matches a particular species.

However, these clues are not enough to identify the majority of the species in Scotia II/ustrata II: 1 for two reasons. First; the text does not always provide any description of the species beyond a vague description of the genus and the polynomial names themselves. Second; Scotia Illustrata was published over fifty years before Linnaeus systematised the binomial nomenclature system in Systema Naturae (Linnaeus, 1735), so the names used can be difficult to identify, and sometimes do not apply to a single species.

Despite this, almost all of the species in Scotia I/lustrata can still be identified due to Robert Sibbald's diligence in providing multiple, pre-Linnaean, polynomial names for each species, accompanied by a botanical authority for each name. Unfortunately, polynomial names cannot be easily searched for yet in herbaria or plant name databases like obsolete post-Linnaean binomial synonyms can be. However in the centuries since Scotia Illustrata was written several botanists have worked to interpret these names based on species descriptions in longer preLinnaean sources and these sources can be referred to in order to identify our species. The following therefore are additional clues:

5. The polynomial or vernacular name used matches a name used in another of Sibbald's books: the History, Ancient and Modern, of the Sheriffdoms of Fife and Kinross, and plant has been identified by the editor as a particular species (Adamson, 1803). 
6. Polynomial or vernacular name used matches a name used in the Description of the Shire of Tweeddale by Sibbald's colleagues Alexander Pennecuik \& John Forbes, and is identified by the editor as a particular species (Allardice, 1815).

7. Polynomial name used is listed, with a corresponding Linnaean binomial, in the polynomial dictionary: A Botanical Arrangement of All the Vegetables Naturally Growing in Great Britain, vols. 1-2 (Withering, 1776a, 1776b).

8. Polynomial name used is listed, with a corresponding Linnaean binomial, in the polynomial dictionary: A Botanical Materia Medica, vols. 1-4 (Stokes, 1812a, $1812 \mathrm{~b}, 1812 \mathrm{c}, 1812 \mathrm{~d}$ ).

9. Vernacular name used is also used in the (1683) Hortus Medicus Edinburgensis by Sibbald's colleague James Sutherland, and has been identified by a modern botanist as a particular species (Robertson, 2001).

10. Polynomial name used is listed, with a corresponding Linnaean binomial, in the manuscript polynomial dictionary The Concordance of Sutherland's (1683) Hortus Medicus Edinburgensis (Kemp \& Balfour, 1912).

11. Polynomial name used is also used in the Cambridge Catalogue by Sibbald's contemporary John Ray, and has been identified by the most recent editors as a particular species (Oswald \& Preston, 2011).

The species in Scotia Illustrata II:1 are classed as 'identified' when at least one of the clues suggests an identification for the species.

The identifications are classed as 'secure' when conditions (a) and (b) are both met:

(a) at least three clues identify the species.

(b) none of the clues from \#3-11 suggest an alternative identification.

Or, alternatively:

(a) at least six clues identify the species.

(b) only one of the clues from \#3-11 suggests an alternative identification.

In cases where either too few clues identify the species to meet condition (a), or too many clues suggest an alternative identification to meet condition (b), the identification has been labelled 'unreliable'. The identifications are presented in the supplementary downloadable spreadsheet and can be seen in context in the text of the full translation (Sibbald, 2020).

\section{Results}

Of the 662 wild species included in Scotia Illustrata II:1, the method outlined above identified $652(98 \%)$ of them but provided secure identifications for $396(61 \%)$ See Fig. 2. There were two main reasons that the identified species could not be securely identified. Some species are not well described by Sibbald meaning there are not enough clues to identify them, whereas some controversial polynomial names seem to have been applied to different species by different authors meaning there is too much disagreement to securely identify them. All of the identifications are included on the accompanying dataset, but the discussion section is based only on the unique species with secure identifications. Of course, we still need to be cautious even with the securely identified species. In some cases, contributors seem to have mis-recorded non-native species in the text so that the text is not an infallible guide to the presence of the species it describes. 


\section{Species in Scotia Illustrata II:1}

Total species in Scotia Illustrata II:1

Identified species

Securely identified species

Unique, securely identified species

" with a Red List status
662

652

396

387

368

Figure 2. How the 662 species included in Scotia IIlustrata II:1 became our 368 securely identified species with a conservation status in the GB Vascular Plant Red List (Cheffings \& Farrell, 2005)

To help set the records in Scotia Illustrata II: 1 in their conservation context and explore ways that the flora of Scotland might have changed between the seventeenth and twenty first century, the dataset also includes the conservation species of each unique, securely identified species according to the Vascular Plant Red Data List for Great Britain (Cheffings \& Farrell, 2005) - hereafter the GB Red List, based on the 2001 IUCN guidelines. 19 (5\%) of the species have not been assigned a conservation status on this list. Most of these species are seaweeds and fungi or crops and casuals, which would not be included on the vascular plant list or were introduced only shortly before 1684. One plant, Agrostemma githago (Corncockle) is on the Waiting List, as it is thought to have become extinct in Britain; it is still regularly found, but the modern individuals may be derived from imported seed rather than a surviving stock (Cheffings \& Farrell, 2005, p. 99). Of the remaining 368 unique, securely identified species which have been assigned an IUCN conservation status, 340 (92\%) are now categorised as least concern on the GB Plant Data List, and 10 (3\%) are near threatened. That leaves 18 species (5\% of those with a status) which are now categorised as threatened with extinction (vulnerable, endangered or critically endangered) on the GB Red List. These, together with species in decline in Scotland will be the most important species to discuss in the discussion section. Interestingly, this figure is much lower than the $20 \%$ of species which are now threatened with extinction across the whole of the GB Red List. (Cheffings \& Farrell, 2005, p. 23) (Fig. 3).

The discrepancy between the percentage of threatened species identified in the dataset for this study and the percentage of threatened species in the whole British flora means that our dataset is not comparable to a modern floral survey. The absence of species from the text need not imply their absence from the area, and the inclusion of other species may not be reflective of their relative abundance. The reason for this bias is not fully clear, but it is possible to exclude some possibly confounding variables by comparing two subsets of the data. In general, Scotia Illustrata II: 1 is focused exclusively on species which have utility for industry or medicine (Sibbald, 1684, p. 6 (II:1)), but an appendix at the end of the text lists all species known to occur around Edinburgh (not just utility species). There is overlap between the datasets, but the appendix does include at least 50 species not found in 
the main text because they are of little utility (e.g. nineteen additional species in the seventeenth century Gramen genus which included many different grasses). It was possible to identify $365(99 \%)$ of the species in the Appendix, of which 313 are unique and have a modern conservation status - these make up our appendix subset. Figure 4 compares the current conservation status of the species in the main text subset, excluding the appendix species, against the current conservation status of the species in the appendix subset.

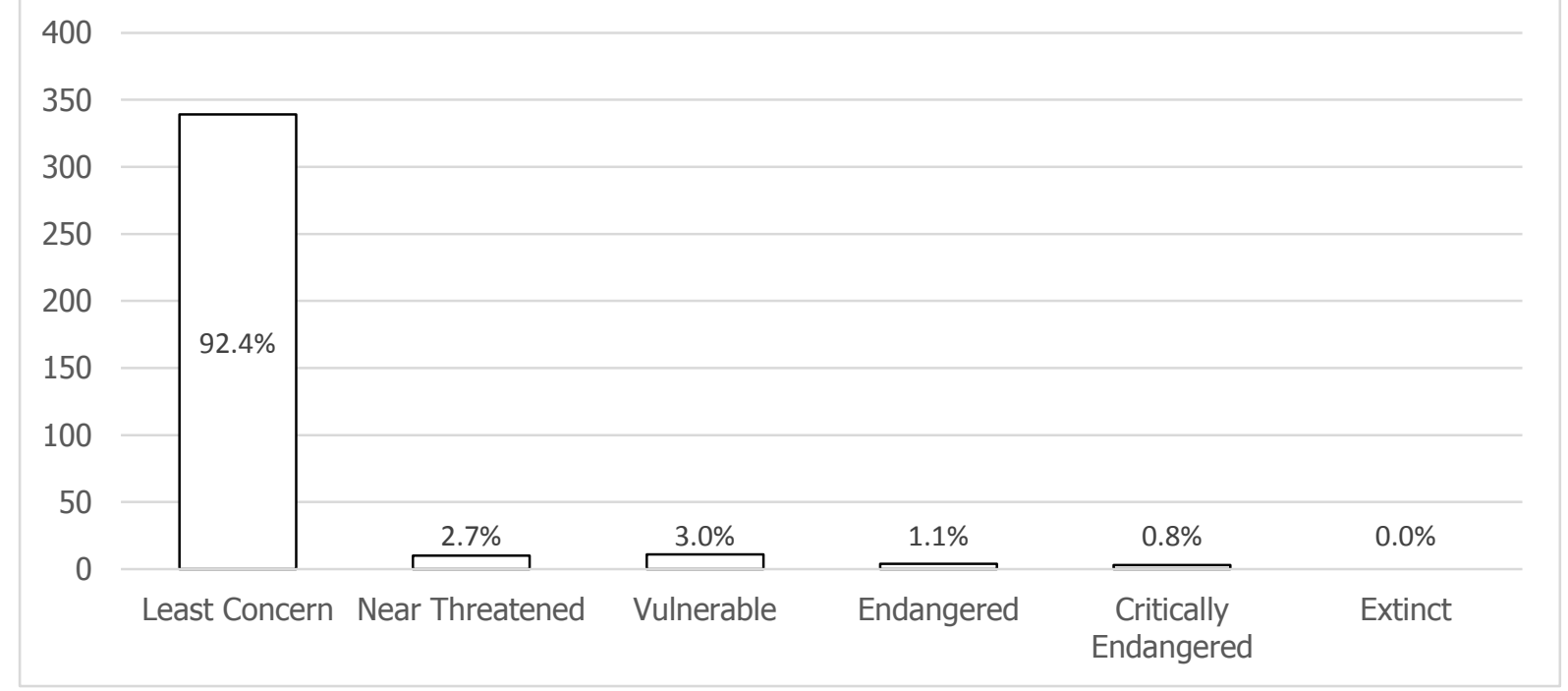

Figure 3. Chart showing the number of species with each conservation status which have been securely identified in Scotia Illustrata II:1.

The two data subsets have very similar proportions of species with each conservation status. That means two possibly confounding variables can be ruled out: First, the fact the main text only includes utility species has not had an effect on the proportion of species in the dataset which are now threatened. If it had an effect, the appendix subset would have shown more threatened species. Second, while the main text subset includes only securely identified species, the appendix subset includes not just securely identified species but also unreliable identifications. This means that the method of this paper (excluding hard-to-identify species from the dataset) has not had an effect on the proportion of remaining species within the dataset which are now threatened. If it had an effect, the appendix subset would have shown more threatened species. It is also worth pointing out that the current GB Red List does not include many of the rare microspecies of Rubus, Hieracium, Taraxacum or Ranunculus which are likely to change the proportion of the Red List which is classified as threatened.

A more likely (but harder to control for) explanation for the discrepancy is a sampling bias. Since the contributors were not aware of the whole flora, the species they were aware of were more likely to be common: The best-known and highest profile species in the seventeenth century are more likely to have been the most widespread and abundant species of the time. These common species may also have been best placed to adapt to changes and exploit new niches as they emerged. This idea has received some support from recorder-data over the last century which tentatively suggests that historically common species are less vulnerable to decline 
than rarer species (Preston et al., 2002, p. 37)). Future researchers could test these theories by comparing the conservation status of species in other comparable historical surveys, as for example the later New Statistical Account of Scotland (1834-45) (Ministers of the Respective Parishes, 1837) which drew on contributions from each parish, and included rare wild plants.

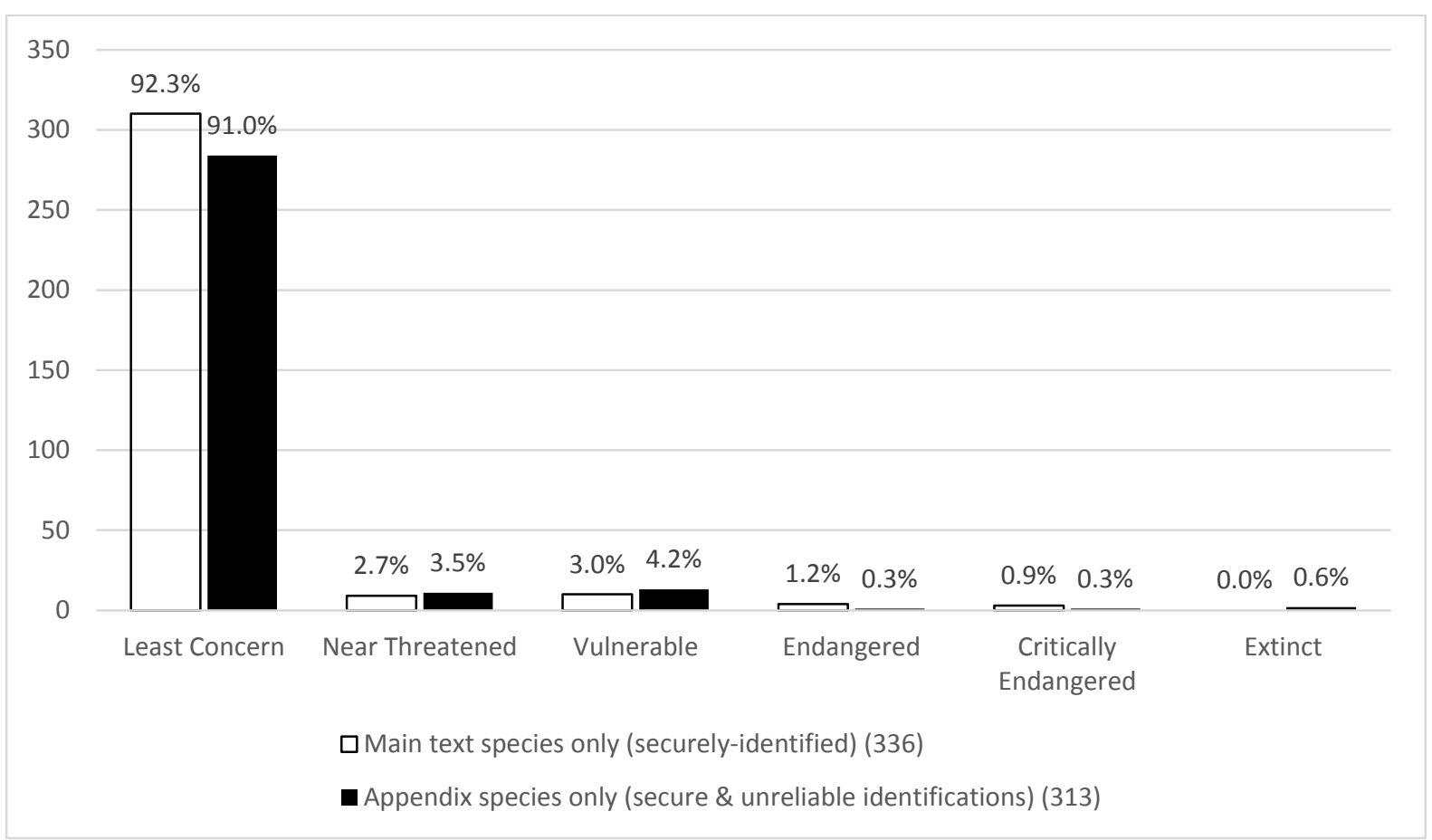

Figure 4. Chart showing the number of identified species with each conservation status in two datasets. The white bars are the species from the main text only, and are securely identified species only. The black bars are the species from the appendix, including both secure and unreliable identifications.

\section{Discussion}

To facilitate further discussion, the plants of Scotia Illustrata II:1 are divided into sections based on their habitats. The term habitat had not been coined in English when Scotia I/lustrata was written, but within the text, 180 plants are noted as growing in (in... nascitur/provenit), or are associated (in their vernacular or polynomial name) with one of the terrain types in Table 1 . This list of habitats does not include gardens (the text deals with garden plants separately in Scotia Illustrata II:2), but it does include weeds on arable land, urban areas and on roads. The terms humidus (damp), and umbrosus (shady) are taken to refer to ordinary growing conditions rather than habitats.

This list of habitats is not as precise as our modern broad habitat index or the priority habitats list. However, despite the limitations of this list, it is worth using as a structure for the Discussion because it provides a point of context within the historical time period. This is important because habitats are not eternally the same: most of those on the list are managed differently now with different stressors to their situation in the seventeenth century. In practice, some species seem to have adapted from one habitat in the seventeenth century to another in the twenty-first due to changes in management. These categories also reconstruct more accurately 
how people in the seventeenth century might have seen the species around them in Scotland.

Table 1. List of habitat types included in Scotia I/lustrata II:1

\begin{tabular}{|l|l|}
\hline Habitat & Terms in text \\
\hline Arable & arvum, ager, field \\
\hline Woodland & sylva, nemus, wood \\
\hline Upland & $\begin{array}{l}\text { mons, montanus, mountain, } \\
\text { moors }\end{array}$ \\
\hline Coastal & rupes marinus, sea \\
\hline $\begin{array}{l}\text { Standing } \\
\text { water }\end{array}$ & $\begin{array}{l}\text { aqua, aquatica, aquosus, lacus, } \\
\text { water }\end{array}$ \\
\hline Marsh & palus, marsh \\
\hline River & fluvius, rivulus, rivus \\
\hline Pasture & pascuus \\
\hline Meadow & pratum, meadow \\
\hline Scrub & dumetum \\
\hline Hedgerow & sepes, hedge \\
\hline Inland rock & saxum, saxosum, saxatilis \\
\hline Road & via \\
\hline Urban & urbs \\
\hline
\end{tabular}

\section{Woodland}

The words used to refer to woodland in Scotia Illustrata II:1 are sy/va (wood), and nemus (grove). The text does not seem distinguish between coniferous and broadleaf woodlands, or between woodlands used for coppice and grazing, and plantation woodlands used only for timber (see Smout, 2009). A few species which have been securely identified are described in the text as being especially common (frequens) or widespread (passim). These include three perennial herbs: Hyacinthoides non-scripta (Bluebell), Ajuga reptans (Bugle) and Lysimachia nemorum (Yellow Pimpernel), but also interestingly Galium aparine (Cleavers), perhaps suggestive of grazed, open canopy woodland, since it is not tolerant of full shade.

One other species is referred to in the text as common. This is Acer pseudoplatanus (Sycamore). Although some scholars take this plant to be native (Dickson, 1998; Green, 2005; Milner, 2011, pp. 133-134; Williamson, 2013, p. 12), our text also provides references to other species which are known more decisively not to be native to Scotland. These include most obviously Helleborus foetidus and especially Fagus sylvatica. It seems probable that Scotia Illustrata II: 1 is therefore including some casual or naturalised woodland species. Acer campestre (Field Maple) is actually described in the text as being found 'amongst the planting at Kinfauns near Perth' (Sibbald, 1684, p. 7 (II:1)). Abies alba (European Silver Fir) is also included despite being certainly non-native and thought to have been first introduced to Britain in only 1603 (Preston et al., 2002, p. 81). It must have been adapted in Scotland very quickly indeed because the text describes the most vast woods of it' in northern Scotland (Sibbald, 1684, p. 6 (II:1)). There may have been 
some confusion in this last reference with Pinus sy/vestris (Scots Pine), since although the text does distinguish the two species, $P$. sylvestris is not given its own entry in Scotia I/lustrata II:1, although it is listed as a horticultural species in the next book (Sibbald, 1684, p. 103 (II:2)). These records indicate that the seventeenth century concept of a 'naturally-occurring plant' in Scottish woodland was flexible. A few other surprising species are included in the text which may have been naturally occurring in the country at the time, assuming the records are not erroneous. These include Crataegus aria agg. (Whitebeam) and Frangula alnus (Alder Buckthorn). These species may be native based on the pollen record (Godwin, 1975, pp. 177, 200). Arum maculatum is widely distributed in the south of Scotland, and it was originally considered by Sowter (1949) to be native to this area.

Euonymus europaeus is thought to be native in Berwickshire at least (P. A. Thomas et al., 2011).

\section{Scrub}

Scotia Illustrata II: 1 uses the word dumetum to refer to scrub (as distinguished from sepes hedgerow). The text uses this term to refer to the habitat of three species, none of which are described as common: Galium odoratum (Sweet Woodruff; also associated in the text with woodland), Cruciata laevipes (Crosswort; also associated with hedgerows) and strangely, assuming the records are correct, Cornus sanguinea. The last is thought to be native only to England and introduced in Scotland, although it is now widely found in the country (Preston et al., 2002, p. 422). This species is likely to have escaped or grown wild from planted hedgerows, along the lines of the anomalous woodland species above.

\section{Inland Rock}

The terms used to refer to inland rock species are saxum (rock), saxatilis (living in rocks) and saxosus (rocky). Some of the contributors to Scotia Illustrata II:1 seem to have been familiar with the inland rock habitats of Scotland, and many taxa are identified in the text as rock-dwellers. Unfortunately, a considerable number of the species described in this habitat are difficult to securely identify. For example, the text describes thirteen taxa in the Adiantum genus, of which it was possible to securely identify only two (Sibbald, 1684, pp. 7-8 (II:1)). One problem here is that the text seems to have split species based on local variations: the thirteen Adiantum taxa include five which are described as diversitas (loosely: varieties) which do not seem to be true species (these have therefore not been included in our dataset). A second problem is a lack of information about the species among later botanists: Among the other Adiantum species which it was not possible to securely identify, one has been unreliably identified as Asplenium fontanum, a species which is now extinct in Britain, and two have been unreliably identified as haircap mosses which were not regularly included by either seventeenth century botanists or the later writers of polynomial dictionaries. However, it was possible to securely identify five species from the text described as common or widespread in inland rock: Asplenium ceterach, Aphanes arvensis, Digitalis purpurea, Geranium lucidum, and Rubus saxatilis, most of which still occur in rocky habitats today. 


\section{Upland}

The words interpreted to refer to upland species in Scotia Illustrata II:1 are mons, montanus, and moor. This does not include species found on braes or hills or dens (valleys) because these landscape features occur in lowland and upland habitats. Perhaps unsurprisingly, given the bias towards lowland areas in the contributions to Scotia Illustrata shown in Fig. 1., even excluding these terms, many of the species described seem to be generalists. This includes the two species described as widespread or common and as upland specialists: Digitalis purpurea (Foxglove) and Lathyrus linifolius (Heath Pea). These species can be found in upland areas in Scotland, but they can also occur in lowlands are more commonly associated with other habitat types. The same can be said of three other species described as occurring in this habitat: Campanula rotundifolia (Harebell), and especially Dipsacus sylvestris (Wild Teasel which only occurs up to 365m) (Harrap, 2014, p. 295). The text does mention two true upland specialists as upland species: Abies alba (discussed above in the Woodland section), and Empetrum nigrum (Crowberry). Other upland species are mentioned in the text without habitats, as for example, Erica tetralix, Erica cinerea, Calluna vulgaris, Genista anglica, Ulex europaeus, Juniperus communis, Salix repens, Vaccinium myrtillus and Rubus chamaemorus.

\section{Coastal}

The seventeenth century terms which are interpreted to refer to coastal plants are littus (shore) and rupes marinus (sea cliffs). Robert Sibbald was especially interested in this habitat. He also wrote a book on Fife and Kinross (ed. Adamson, 1803) and drafted a manuscript describing the marine animals of the Firth of Forth (Sibbald, 1701). Scotia Illustrata lists several species as occurring on the shores of the Firth of Forth: Calystegia soldanella, Seriphidium maritimum, Mertensia maritima, Chenopodium vulvaria. The last of these is an archaeophyte and now endangered in Britain. Gerard (1597, p. 258) describes it as most common around outdoor latrines. It was formerly dependent on dung-enriched soil, and seems to have declined following the decrease in the use of horses and of dung as a fertiliser (Preston et al., 2002, p. 138). This plant is still found in the Firth of Forth in modern times. Two other now declining species are also referred to in the text as coastal. (i) Centaurea calcitrapa (Red Star-thistle) which was previously common on waste grounds and elsewhere (National Biodiversity Network, 2020b; Preston et al., 2002, p. 616) ${ }^{1}$. (ii) Kali turgidum synonym Salsola kali subsp. kali (Prickly Saltwort) is also mentioned as a coastal species, and is now classed as vulnerable. This species is in decline due to development (Preston et al., 2002, p. 148).

Although still currently classified as least concern on the GB Red List, two other records are of interest here. Eryngium maritimum (Sea Holly) is described in the text as growing 'By the sea-side in several places, but most abundantly near Dumbar (=Dunbar) and near Largo upon Fife-side' (Sibbald, 1684, p. 22 (II:1)). This population may now be extinct. According to the National Biodiversity Network Atlas records from the last ten years (2020c), the species is now almost exclusively found

\footnotetext{
${ }^{1}$ Here and elsewhere in the following discussion there are references to the modern range of a species as recorded in the online National Biodiversity Network Atlas. The NBN Atlas currently applies the same weight to historical records as to modern records, so to follow these citations readers will need to filter the most recent records by year using the interactive version of the map.
} 
in south east Scotland. Marrubium vulgare (White Horehound), meanwhile has not been recorded in Scotland at all for the last ten years (National Biodiversity Network, $2020 \mathrm{~g}$ ). Prior to that time, it was found in a handful of sites in the Firth of Forth. Its former presence on these sites was usually thought to be as a neophyte (Preston et al., 2002, p. 516), but our text records it as one of the species found in the area surrounding Edinburgh (Sibbald, 1684, p. 59 (II:1)). Sibbald elsewhere records a population on Inchgarvie (ed. Adamson, 1803, p. 147), and there are other old records from Scotland (e.g. Ministers of the Respective Parishes, 1837, p. 235), which might suggest the population in East Lothian was actually native.

\section{Standing water}

Scotia Il/ustrata II: 1 is quite nuanced in its descriptions of freshwater habitats, and distinguishes rivers and swamps from standing water. Standing waters are referred to as aqua, aquatica, aquosus (standing water) and lacus (loch). The only species referred to as common or widespread in this habitat and not the others is Angelica sylvestris but the text also refers to Phragmites australis, Schoenoplectus lacustris, Alnus glutinosa and Bidens tripartita as occurring here. Although not attributed to this habitat by the text, Scotia Illustrata II:1 does record a few other standing water and bog specialists such as Nymphaea alba, Nymphoides peltata, Myrica gale and Drosera rotundifolia.

One surprising inclusion of a freshwater species, assuming the record is reliable, is Hydrocharis morsus-ranae (Frogbit) which has declined and is now classed as vulnerable on the GB Red List. This species is usually thought to be native only to the south of Britain, and not Scotland (Forbes, 2003; Godwin, 1975, pp. 355356; Preston et al., 2002, p. 669), but since there are records of native populations in Northumbria and Lough Neagh it seems possible this species did once occur in the south of Scotland before its decline. An introduced population has become established in the central belt of Scotland over the last 30 years (National Biodiversity Network, 2020d). Another vulnerable species, Persicaria minor (Small Water-pepper), now known mainly in south east Scotland, is also attested in our text.

Marsh

Palus is the term attached to marshland in Scotia Illustrata II:1. One species is referred to as common in this habitat which is Iris pseudacorus (Yellow Iris). The text also lists several other typical species as living here including Lemna minor, Mentha aquatica, Typha latifolia, Menyanthes trifoliata and Vaccinium oxycoccos. Almost all of the marshland species referred to in the text are still common today. The most unexpected record, assuming it is reliable, is that of Valeriana dioica (Marsh Valerian), which is on the edge of its current range in Scotland.

\section{Rivers}

In the seventeenth century text, river habitats are indicated by the terms fluvius (river), and rivulus and rivus (stream). This list does not include species found on banks since the areas called banks can stretch into other habitats. One species referred to as widespread alongside rivers is Filipendula ulmaria (Meadowsweet), which is also described as occurring in meadows, but several other typical river 
species are included like Helosciadium nodiflorum, synonym Apium nodiflorum, Nasturtium officinale, Cicuta virosa, Urtica dioica, Salix alba and Salix fragilis.

The only surprising river species mentioned in the text other than Persicaria minor, discussed above is Sium latifolium (Great Water-parsnip). This record may well be reliable. This species is now classed as endangered on the GB Red List, and is extinct in Scotland, with no secure records from the last fifty years (National Biodiversity Network, 2020i; Preston et al., 2002, p. 460). In the past it has sometimes been considered native only to the south of England (Godwin, 1975, p. 225), but sufficient early records exist to prove that the species was formerly found in Scotland as well (Lusby, 1998, p. 54), and Scotia Illustrata II:1 fits with these. The species has declined over the last century due to drainage and poor management.

\section{Pasture}

The term used for pasture in the seventeenth century Scotia Illustrata II: 1 is pascuus which is distinguished from agrum (agricultural field) and pratum (meadow). This term is rare in the text, but is used to refer to Bellis perennis (Daisy) and Filipendula vulgaris (Dropwort; now rare in Scotland). The text also lists other pasture species, but without describing their habitat including Taraxacum agg. (unsurprisingly described in the text as widespread) Plantago major and Conopodium majus.

\section{Meadow}

The seventeenth century terms used for meadow species in Scotia Illustrata II:1 are pratum (meadow) and pratensis (found in meadows). These terms are used to describe several securely identified and familiar plants in our text, including Rhinanthus minor, Filipendula ulmaria, Knautia arvensis, Succisa pratensis and Veronica serpyllifolia. Some of those indicated are harder to reconcile with modern meadows and have special requirements. For example, Rumex acetosella and Anthyllis vulneraria need free draining soil; Silene flos-cuculi, synonym Lychnis floscuculi and Achillea ptarmica need damp soil; Odontites vulgaris, synonym Odontites vernus likes compacted soil. That these plants were thought of as meadowspecialists might suggest the presence of meadows-pasture hybrids and water meadows as well as the summer hay meadows which still exist today (J. Mitchell, 1997; Williamson, 2013, p. 38).

Just like with the woodland species, there are some meadow species which are included in Scotia Illustrata II:1, but whose native range in Britain is usually thought to exclude Scotland. These are Cirsium eriophorum, Pimpinella major and Viola odorata. The first of these, was recorded in the text 'on the sea-side betwixt Blackness and Queensferry' (along with Centaurea calcitrapa!) (Sibbald, 1684, p. 15 (II:1)). The names given by the text for this plant have been securely identified by four sources as synonyms for Cirsium eriophorum (Woolly Thistle). However, the plant itself seems to have been wrongly recorded. The plant Sibbald saw is more likely to have been the hairy form of Cirsium vulgare (Druce, 1924, p. 41), although the plant has occasionally been recorded in Scotland as a casual (Tofts, 1999). Either way, the reference in Scotia Illustrata II:1 is unlikely to reflect a previously more northerly limit to the species' native range. The same is likely to be true of Viola odorata (Sweet Violet). Scotland seems to be the edge of its natural range, and 
it has been widely planted in the past. The last record may reflect a change in native range: Pimpinella major (Greater Burnet-saxifrage) is now present in Scotland only as an introduced plant, but since its known native population extends right up to the border, and it was in decline prior to 1930 , it seems possible it did once occur as a native in south Scotland (Preston et al., 2002, p. 459).

\section{Arable}

The terms used to describe arable land in Scotia I/lustrata II:1 are arvum (ploughed land) and ager (field). Our arable specialist flora is known to have been severely impacted by the twentieth century agricultural revolution and increase in the use of pesticides, especially the archaeophyte species (Ingrouille, 1995, p. 275; Robinson \& Sutherland, 2002). This category therefore includes more rare species than any of the others.

To start with, three arable species mentioned in the text are now extinct in Scotland. Lolium temulentum (Darnel) is critically endangered on the GB Red List. It has only been recorded in two locations in Britain in the last thirty years, neither of which are in Scotland (National Biodiversity Network, 2020f). It seems to have been widespread and hated in the past ( $\mathrm{H}$. Thomas et al., 2016). The reason for this was that it could contaminate and potentially poison a harvest of cereals. Our text explains: 'In bread or beer, it quickly brings drunkenness, or more so vertigo. It also does harm to the eyes' (Sibbald, 1684, p. 36 (II:1)). The second now-extinct plant, Scandix pecten-veneris (Shepherd's Needle), was better liked. It is described as having five different medical uses in our text (Sibbald, 1684, p. 48 (II:1)). It seems to have been mainly confined to eastern Scotland even when it was common, but it has now declined due to the use of modern pesticides, and it is classed as critically endangered on the GB Red List (Lusby, 1998; Wilson, 2006). Euphorbia exigua (Dwarf Spurge) lost its Scottish population slightly earlier than this, but probably for similar reasons. It is now classed as near threatened in the GB Red List. Anthemis cotula (Stinking Chamomile) is described as widespread - 'found everywhere' in our text (Sibbald, 1684, p. 17 (II:1)). Like L. temulentum, this species appears to have been especially hated because its achenes could cause blistering and it was resistant to scything and grazing (Ingrouille, 1995, pp. 248250). Perhaps because of this it has steeply declined over the last sixty years due to the increased use of modern pesticides, and is now classed as vulnerable on the $G B$ Red List. (Preston et al., 2002, p. 648). From being found everywhere in the seventeenth century this species is only recorded in seven locations in twenty-first century Scotland, and over half the these records are from the Outer Hebrides (National Biodiversity Network, 2020a). A few other arable species are mentioned in the text which are rare in Scotland: Lithospermum arvense is described in Scotia Illustrata II:1 as the 'bastard alkanet or bastard gromell' which 'grows among the wheat' (Sibbald, 1684, pp. 9-10 (II:1)). It is now endangered on the GB Red List. Over the last fifteen years, it has only been recorded in Scotland in the past, especially in the Outer Hebrides, but it was commonly recorded in Scotland especially on the east coast (National Biodiversity Network, 2020e; Preston et al., 2002, p. 495).

Scotia Illustrata II: 1 also surprisingly contains a reference to Epilobium tetragonum (Square-stalked Willow-herb). This species has sometimes been recorded in Scotland in the past (e.g. Kenneth, 1971; Ministers of the Respective 
Parishes, 1837, p. 324), but the records have been difficult to confirm and are likely to be mistakes for E. obscurum (Short-fruited Willow-herb; Preston et al., 2002, p. 414). Our record of this species is likely to be a mistake for $E$. obscurum, as the latter species is not otherwise included in the text.

There is one final reference to an arable plant which is anomalous, if it is reliable. Myosurus minimus (Mousetail) is native to Britain, and it seems to have reduced its range over the last century. There does not seem to be much other historical evidence of it occurring in the wild in Scotland (Preston et al., 2002, p. 111). However, over the last three years it has been newly recorded around Lairg in Sutherland. (BSBI database accessed 2020, https://database.bsbi.org/).

\section{Hedgerow}

Scotia Illustrata II: 1 uses the terms sepes and hedge for hedgerow. The securely identified species described in the text as occurring in this habitat are: Alliaria petiolata, Torilis japonica, Aegopodium podagraria, Stachys sy/vatica and Cruciata laevipes. Interestingly, these are all herbaceous species. There is a note under Crataegus monogyna saying 'it is the most useful shrub for live hedges' (Sibbald, 1684 , p. 38 (II:1)), but this is under 'use' not under 'location'. The author may have felt uncomfortable with listing any planted specimens amongst the 'naturally occurring plants of Scotland'.

A few other hedgerow species mentioned in the text are of interest. First, Scotia Illustrata II: 1 includes a reference to Nepeta cataria (Catmint). This species is differentiated in the text from a smaller garden variety ( $N$. nepetella?), so this reference cannot be explained as a garden escape. $N$. cataria is now classed as vulnerable in the GB Red List. It is very rare in Scotland, with only two populations recorded in the last fifteen years. This may be a result of a contraction in range, although it was described as very rare even at the end of the nineteenth century (National Biodiversity Network, 2020h; Preston et al., 2002, p. 520; Ramsay, 1876). The text also describes a verticillate herb called 'Verbena vulgaris... common vervain'. This is usually interpreted as Verbena officinalis. $V$. officinalis is an archaeophyte that seems to have been lost very early from Scotland. It was remembered, but not found at the time of the New Statistical Account of Scotland (Ministers of the Respective Parishes, 1837, p. 235). The record in Scotia Illustrata II: 1 is therefore of importance for securing its presence in the seventeenth century. Similarly, the reference in the text to Lithospermum officinale (Common Gromwell) supports the theory that this species is native to Scotland (Preston et al., 2002, p. 495), despite its rarity in the country today. Finally, there is also a reference to the archaeophyte Blitum bonus-henricus, synonym Chenopodium bonus-henricus (Good King Henry), which is now listed as vulnerable on the GB Red List.

\section{Highway}

The term used for a highway in the text is via. This is not usually thought of as a habitat type today, but the highways of the past may well have had their own specialist species, like our roadside verges and railway embankments do today. Scotia Illustrata II:1 identifies two species as widespread road-specialists: Cynoglossum officinale (Hound's-tongue) and Hyoscyamus niger (Henbane). Neither of these species are recorded as widespread in records from Scottish recorders in the twentieth century (Preston et al., 2002), and they are both listed under rare 
plants in the nineteenth century New Statistical Surveys of Scotland (e.g. Ministers of the Respective Parishes, 1837, p. 234). They are now mainly coastal species and rare. In fact it has been argued that $C$. officinale may not have even been native in Scotland at all (de Jong et al., 1990; Preston et al., 2002, p. 506). If the record of the two species as widespread in Scotia I/lustrata II:1 is to be trusted, and they were specialist highway weeds, it seems possible that they declined due to the eighteenth century revolution in military road building after the Jacobite uprisings (on which, see: Guldi, 2012, pp. 8-13). The two species continue to decline today due to the increased use of pesticides. $C$. officinale is now classed as near threatened and $\mathrm{H}$. niger is classed as vulnerable on the GB Red List.

\section{Urban}

The term used for urban areas in the text is urbs (a city). Only one species is listed in Scotia Il/ustrata II:1 as an urban specialist, Conium maculatum (Hemlock). This species is listed as common in the text and remains common in urban areas today. Unfortunately, it is difficult to identify the urban species of the seventeenth century beyond this. Williamson $(2013$, p. 53$)$ suggests that fast-growing species may have dominated in early modern English towns. Of the species he suggests, Blitum bonushenricus and Circaea lutetiana are found in our list of Scottish plants, but their habitat is not mentioned. Similarly, several other species commonly found in towns today like Epilobium montanum, Senecio vulgaris, and Asplenium trichomanes are also included in the text without a stated habitat, but most urban species are generalists and therefore they could just as easily have passed the seventeenth century outside of urban areas. Other generalist species which are not as commonly found in urban areas in Scotland today may have been better adapted to the urban areas of the seventeenth century.

\section{Summary}

This paper analysed the 662 wild plants listed in Robert Sibbald's Scotia Illustrata II:1. Based on common name, description, plate and polynomial name, it was possible to securely identify 387 unique species from this list. These securely identified species are discussed within their habitat groupings in the Results above, and special attention is paid to the species which are now threatened on the British Red List. By analysing the species within their habitats, we can see some patterns. Most obviously, several of the arable species mentioned in the text have declined, and at least three (Lolium temulentum, Scandix pecten-veneris and Euphorbia exigua) are now extinct in Scotland. This likely reflects the changes to the habitat during the agricultural revolution. The species mentioned in 1684 as widespread on highways (Cynoglossum officinale and Hyoscyamus niger) are no longer widespread anywhere in Scotland, suggesting that their ecological niche has also been lost. By contrast, the woodland and hedgerow species mentioned in the seventeenth century text already include several non-natives (e.g. Fagus sy/vatica, Acer campestre and Cornus sanguinea) which supports the argument that planned planting was already extensive in the wooded areas of seventeenth century Scotland.

\section{Acknowledgements}

This research was funded by grants from the Alice McCosh Trust, the Wild Flower Society and the Botanical Research Fund. A copy of the unpublished Concordance of 
Sutherland's (1683) Hortus Medicus Edinburgensis was provided by Graham Hardy and Marcia Rodriguez at the Royal Botanic Garden Edinburgh. The Greek plant names were extracted by Maddy Young. Greg Kenicer and Laurie Raye kindly edited the first draft of the manuscript. I would like to especially thank Ian Denholm, David Pearman and the anonymous commenters at British \& Irish Botany for their patient suggestions.

\section{References}

Adamson, L. 1803. Robert Sibbald: The History, Ancient and Modern, of the Sheriffdoms of Fife and Kinross. London: R. Tullis. Available at: https://books.google.co.uk/books?id=gGIBAAAAYAAJ\&

Allardice, A. 1815. The works of Alexander Pennecuik, Esq. of New Hall, M.D. London: Longman \& Co. Available at: https://books.google.co.uk/books?id=9vBBAAAAYAAJ\&

Aubrey, J. 1691. The natural history of Wiltshire (J. Britton (ed.), 1847). Salisbury: Wiltshire Topographical Society.

Bleay, N. J. 1987. The ecology of sycamore in British woodland. Master's thesis at Middlesex Polytechnic. Available at: http://eprints.mdx.ac.uk/9845/

Boyle, M. 1665. General Heads for a Natural History of a Countrey, Great or Small, Imparted Likewise by Mr. Boyle. Philosophical Transactions of the Royal Society of London, 1(11): 186-189. Available at: https://royalsocietypublishing.org/doi/10.1098/rstl.1665.0082

Boyle, R. 1666. General Heads for the Natural History of a Country, Great Or Small: Drawn Out for the Use of Travellers and Navigators. London: John Taylor at the Ship in S. Paul's Church-yard, and S. Holford, at the Crown in the Pall Mall.

Childrey, J. 1662. Britannia Baconica. London: Printed by the author.

Cooper, A. 2007. Inventing the indigenous: Local knowledge and natural history in early modern Europe. Cambridge: Cambridge University Press.

de Jong, T. J. Klinkhamer, P. G. L. \& Boorman, L. A. 1990. Cynoglossum Officinale L. Journal of Ecology, 78(4): 1123-1144. <https://doi.org/10.2307/2260956>

Dickson, J. H. 1998. Plant introductions in Scotland. In R. A. Lambert (Ed.), Species History in Scotland (pp. 38-44). Edinburgh: Scottish Cultural Press.

Cheffings, C.M. \& Farrell, L. (Eds), 2005. The Vascular Plant Red Data List for Great Britain. Species Status 7: 1-116. Joint Nature Conservation Committee, Peterborough.

Dodgshon, R. A. 2005. The Little Ice Age in the Scottish Highlands and Islands: documenting its human impact. Scottish geographical journal, 121(4): 321-337. <https://doi.org/10.1080/00369220518737243>

Druce, G. C. 1924. Plant notes, etc. for 1923. In Botanical society and exchange club of the British Isles 7(1):11-75. Available at:

http://archive.bsbi.org.uk/BEC 1923 Vol 7 pt 1.pdf

Emery, F. 1977. Edward Lhuyd and A natural history of Wales. Studia Celtica, 12: 247.

Forbes, R. S. 2003. Criteria for assessing the native status of British plants: some case histories. In C. P. Biggam (Ed.), From Earth to art: the many aspects of the plant-world in Anglo Saxon England (Vol. 148, pp. 79-100). Amsterdam: Rodopi.

Fox, A. 2010. Printed questionnaires, research networks, and the discovery of the 
British Isles, 1650-1800. Historical Journal, 53(3): 593-621.

Gerard, J. 1597. The herball. London: Iohn Norton.

Godwin, H. 1975. The history of the British flora (2nd ed.). Cambridge: Cambridge University Press.

Green, T. 2005. Comment: Is there a case for the Celtic Maple or the Scots Plane? British Wildlife, 16(3): 184-188.

Guldi, J. 2012. Roads to power: Britain invents the infrastructure state. Cambridge: Harvard University Press.

Harrap, S. 2014. Harrap's Wild Flowers. London: Bloomsbury Publishing.

Ingrouille, M. 1995. Historical ecology of the British flora. London: Chapman \& Hall.

Kemp, W. D. \& Balfour, I. B. 1912. Concordance of Sutherland's (1683) Hortus Medicus Edinburgensis. Unpublished archive at National Botanic Garden Edinburgh. GB235 SUT, box 4 of 5.

Kenneth, A. G. 1971. The flora of Danna: a supplement. Transactions of the Botanical Society of Edinburgh, 41(2): 155-164.

Linnaeus, C. (1735). Systema naturae, sive regna tria naturae systematice proposita per classes, ordines, genera, \& species. Leiden: Haak.

Lusby, P. 1998. On the extinct plants of Scotland. In R. Lambert (Ed.), Species History in Scotland: Introductions and Extinctions since the Ice Age (pp. 4562). Edinburgh: Scottish Cultural Press.

Milner, E. 2011. Trees of Britain and Ireland. London: Natural History Museum.

Ministers of the Respective Parishes. 1837. The new statistical account of Scotland, no. XIII. London: William Blackwood and Sons. Available at: https://books.google.co.uk/books?id=EtE9AAAAcAAJ\&

Mitchell, A. 1908. Geographical Collections Relating to Scotland made by Walter MacFarlane, vol. 3. Edinburgh: Edinburgh University Press. Available at: https://archive.org/details/geographicalcol01macfgoog

Mitchell, J. 1997. Wet meadows in lowland west central Scotland - an almost forgotten botanical habitat. Botanical Journal of Scotland, 49(2): 341-345, DOI: $10.1080 / 03746609708684878$

National Biodiversity Network. 2020a. Anthemis cotula L. National Biodiversity Network Atlas. Available at: https://species.nbnatlas.org/species/NBNSYS0000004448

National Biodiversity Network. 2020b. Centaurea calcitrapa L. National Biodiversity Network Atlas. Available at: https://species.nbnatlas.org/species/NBNSYS0000004510

National Biodiversity Network. 2020c. Eryngium maritimum. National Biodiversity Network Atlas. Available at: https://species.nbnatlas.org/species/NBNSYS0000003636

National Biodiversity Network. 2020d. Hydrocharis morsus-ranae L. National Biodiversity Network Atlas. Available at: https://species.nbnatlas.org/species/NBNSYS0000002109

National Biodiversity Network. 2020e. Lithospermum arvense L. National Biodiversity Network Atlas. Available at:

https://species.nbnatlas.org/species/NBNSYS0000004017

National Biodiversity Network. 2020f. Lolium temulentum L. National Biodiversity Network Atlas. Available at: https://species.nbnatlas.org/species/NBNSYS0000002530 
National Biodiversity Network. 2020g. Marrubium vulgare L. National Biodiversity Network Atlas. Available at: https://species.nbnatlas.org/species/NBNSYS0000004258

National Biodiversity Network. 2020h. Nepeta cataria L. National Biodiversity Network Atlas. Available at: https://species.nbnatlas.org/species/NBNSYS0000004256

National Biodiversity Network. 2020i. Sium latifolium. National Biodiversity Network Atlas. Available at: https://species.nbnatlas.org/species/NBNSYS0000003685

Oswald, P. H. \& Preston, C. D. 2011. John Ray's Cambridge Catalogue (1660). London: The Ray Society.

Plot, R. 1677. The Natural History of Oxford-shire. Oxford: The Theater in Oxford. Available at: https://books.google.co.uk/books?id=EUqd M1x40QC\&

Plot, R. 1686. The Natural History of Stafford-shire. Oxford: Printed in the Theatre. Available at: https://books.google.co.uk/books?id=T03JVJkdC9gC\&

Preston, C D Telfer, M. G. Roy, D. B. Carey, P. D. Hill, M. O. Meek, W. R. Rothery, P. Smart, S. M. Smith, G. M. \& Walker, K. J. 2003. The changing distribution of the flora of the United Kingdom: technical report. Huntingdon: Centre for Ecology \& Hydrology.

Preston, Christopher D Pearman, D. \& Dines, T. D. 2002. New atlas of the British \& Irish flora. Oxford: Oxford University Press.

Ramsay, J. 1876. On the vascular flora of the west of Scotland. In Notes on the fauna and flora of the west of Scotland (pp. xxi-xxiv). Glasgow: Blackie \& Son.

Robertson, F. W. 2001. James Sutherland's "Hortus Medicus Edinburgensis" (1683). Garden History, 29(2): 121-151.

Robinson, R. A. \& Sutherland, W. J. 2002. Post-war changes in arable farming and biodiversity in Great Britain. Journal of Applied Ecology, 39(1): 157-176. < https://doi.org/10.1046/j.1365-2664.2002.00695.x>

Sibbald, R. 1684. Scotia Illustrata. Edinburgh: James Kniblo, Josuah van Solingen \& Jan Colmar. Available at: https://books.google.co.uk/books?id=PRoAAAACAAJ\&

Sibbald, R. 1699. Provision for the Poor in times of dearth and scarcity. Edinburgh: James Watson.

Sibbald, R. 1701. An account of the fishies and other aquatick animals taken in the Firth of Forth. In Caetologia, etc. Unpublished archive: National Library of Scotland Adv Mss 33.5.16.

Sibbald, R. 1833. The Autobiography of Sir Robert Sibbald, KNT., M.D. Edinburgh: Thomas Stevenson.

Sibbald, R. 2020. The wild plants of Scotland and The animals of Scotland. (L. Raye (trans.)). Cardiff: KDP.

Smith, C. 1746. The ancient and present state of the county and city of Waterford. A. Reilly. Available at: https://books.google.co.uk/books?id=rgA-AAAAcAAJ\&

Smith, C. 1750. The ancient and present state of the county and city of Cork. Dublin: A. Reilly. Available at: https://books.google.co.uk/books?id=dT9IAAAAMAAJ\&

Smout, T. C. 2009. Exploiting Scottish Semi-Natural Woods, 1600-1850. In T. C. Smout (Ed.), Exploring Environmental History (pp. 53-70). Edinburgh: Edinburgh University Press.

Sowter, F. A. 1949. Arum Maculatum L. Journal of Ecology, 37(1): 207-219. $<$ https://doi.org/10.2307/2256754> 
Stokes, J. 1812a. A botanical materia medica, vol. 1. J. London: Johnson and Co. Available at: https://books.google.co.uk/books?id=9QEAAAAAQAAJ\&

Stokes, J. 1812b. A botanical materia medica, vol. 2. J. London: Johnson and Co. Available at: https://books.google.co.uk/books?id=mAYAAAAAQAAJ\&

Stokes, J. 1812c. A botanical materia medica, vol. 3. J. London: Johnson and Co. Available at: https://books.google.co.uk/books?id=PIOfAAAAYAAJ\&

Stokes, J. 1812d. A botanical materia medica, vol. 4. J. London: Johnson and Co. Available at: https://books.google.co.uk/books?id=jYQfAAAAYAAJ\&

Thomas, H. Archer, J. E. \& Turley, R. M. 2016. Remembering darnel, a forgotten plant of literary, religious, and evolutionary significance. Journal of Ethnobiology, 36(1): 29-44. https://doi.org/10.2993/0278-0771-36.1.29

Thomas, P. A. El-Barghathi, M. \& Polwart, A. 2011. Biological Flora of the British Isles*: Euonymus europaeus L. Journal of Ecology, 99(1): 345-365. https://doi.org/10.1111/j.1365-2745.2010.01760.x

Tofts, R. 1999. Cirsium eriophorum (L.) Scop. (Carduus eriophorus L.; Cnicus eriophorus (L.) Roth). Journal of Ecology, 87(3): 529-542.

Williamson, T. 2013. An environmental history of wildlife in England 1650-1950. London: Bloomsbury Academic.

Wilson, P. 2006. Scandix pecten-veneris Dandy. Plantlife International. Available at: https://www.plantlife.org.uk/application/files/2414/7913/4088/Scandix pectenveneris dossier.pdf

Withering, W. 1776a. A botanical arrangement of all the vegetables naturally growing in Great Britain, vol. 1. Birmingham: M. Swinney. Available at: https://books.google.co.uk/books?id=MfsnAAAAYAAJ\&

Withering, W. 1776b. A botanical arrangement of all the vegetables naturally growing in Great Britain, vol. 2. Birmingham: M. Swinney. Available at: https://books.google.co.uk/books?id=km8-AAAAcAAJ\&

Withers, C. W. J. 2001. Geography, science and national identity: Scotland since 1520. Cambridge: Cambridge University Press.

Copyright retained by author(s). Published by BSBI under the terms of the Creative Commons Attribution 4.0 International Public License.

ISSN: $2632-4970$

https://doi.org/10.33928/bib.2020.02.240 